\title{
First outbreak and subsequent cases of Trypanosoma vivax in the state of Goiás, Brazil
}

\author{
Primeiro surto e casos subsequentes de Trypanosoma vivax no Estado de Goiás, Brasil \\ Thiago Souza Azeredo Bastos ${ }^{1}$; Adriana Marques Faria ${ }^{1}$; Darling Mélany de Carvalho Madrid ${ }^{1}$; Luciana Cardoso de Bessa ${ }^{1}$; \\ Guido Fontgalland Coelho Linhares ${ }^{1}$; Otavio Luiz Fidelis Junior ${ }^{2}$; Paulo Henrique Sampaio ${ }^{2}$; Breno Cayeiro Cruz ${ }^{2}$; \\ Leonardo Bueno Cruvinel ${ }^{1}$; João Eduardo Nicaretta ${ }^{1}$; Rosangela Zacarias Machado ${ }^{2}$; Alvimar José da Costa ${ }^{2}$; \\ Welber Daniel Zanetti Lopes ${ }^{1,3 *}$

\begin{abstract}
${ }^{1}$ Departamento de Parasitologia Veterinária, Escola de Veterinária e Zootecnia - EVZ, Universidade Federal de Goiás - UFG, Goiânia, GO, Brasil

2 Faculdade de Ciências Agrárias e Veterinárias, Universidade Estadual Paulista “Júlio de Mesquita Filho” - UNESP, Jaboticabal, SP, Brasil

${ }^{3}$ Instituto de Patologia Tropical e Saúde Pública - IPTSP, Universidade Federal de Goiás - UFG, Goiânia, GO, Brasil
\end{abstract}

Received December 14, 2016

Accepted March 21, 2017

\begin{abstract}
Trypanosomiasis caused by Trypanosoma vivax has increased the reports in Brazil in the last decade. An outbreak is herein first reported in the state of Goiás, from May 2016 to January 2017. The outbreak start occurred in the city of Ipameri (Goiás) after the introduction of 18 auctioned cows from the state of Minas Gerais. Direct parasitological test (blood smears) and polymerase chain reactions targeting the catL genes diagnosed T. vivax infection. Fifty six cows from a herd of 161 were infected; 12 died during the outbreak and 44 animals persistently positive (by blood smears) even after chemical treatment were discarded. After this first case, five other cases were detected in state of Goiás. The spread of this disease can be linked to the commercialization of animals carrying T. vivax, allied to the iatrogenic transmission practice, using a single needle and syringe for all cows, during oxytocin administration before each milking.
\end{abstract}

Keywords: Bovines, lactating cows, oxytocin, PCR, Trypanosomiasis, T. vivax.

\section{Resumo}

Tripanossomíase causada por Trypanosoma vivax tem sido reportada em várias regiōes do Brasil na última década. Um surto é aqui reportado no Estado de Goiás, de maio de 2016 a janeiro de 2017. O início do referido surto ocorreu na cidade de Ipameri (Goiás) depois da introdução de 18 vacas Girolando, provenientes do Estado de Minas Gerais. Pelo exame parasitológico direto (esfregaço sanguíneo) e pela reação em cadeia pela polimerase, identificou-se a infecção por T. vivax nos animais. Cinquenta e uma vacas de um rebanho de 161 foram infectadas; 12 morreram durante o surto e 44 animais permaneceram positivos (pelo esfregaço sanguíneo) mesmo recebendo tratamento químico (diminazene), e foram descartadas. Após esse primeiro caso, foram detectados outros cinco casos no Estado de Goiás. A disseminação dessa doença pode estar ligada à comercialização de animais portadores de $T$. vivax, aliada à prática de transmissão iatrogênica, utilizando-se uma única agulha e seringa para, todas as vacas, durante a administraçáo da oxitocina antes de cada ordenha.

Palavras-chave: Bovinos, vacas em lactação, oxitocina, PCR, Tripanossomíase, T. vivax.

\section{Introduction}

Among the trypanosomes causing disease in livestock T. vivax is one of the most important pathogenic species for livestock animals. (LINHARES et al., 2006). There are two modes of transmissions

*Corresponding author: Welber Daniel Zanetti Lopes. Instituto de Patologia Tropical e Saúde Pública - IPTSP, Universidade Federal de Goiás - UFG, Rua 235, s/n, Setor Leste Universitário, CEP 74605-050, Goiânia, GO, Brasil. e-mail:wdzlopes@hotmail.com for T. vivax in cattle. The cyclical (Tsetse flies in Africa) and mechanical transmission (Africa and other regions, south America, Asia, etc) contamined fomites or by hematophagous insects as tabanids, Stomoxys calcitrans (DAGNACHEW \& BEZIE 2015) or even Haematobia irritans, according to Cadioli et al. (2012). This protozoon originated in Africa and the disease reached South America around 1830 through transporting naturally infected cattle from Africa (SILVA et al., 1996). 
T. vivax has now been diagnosed in several states in Brazil: Pará, Amapá, Mato Grosso, Mato Grosso do Sul, Paraíba, Maranhão, Tocantins, Minas Gerais, São Paulo, Rio Grande do Sul, Pernambuco and Alagoas (SERRA-FREIRE, 1981; SILVA et al., 1996, 2009; PAIVA et al., 2000; BATISTA et al., 2007; GUERRA et al., 2008; LINHARES et al., 2006; CARVALHO et al., 2008; CADIOLI et al., 2012; PIMENTEL et al., 2012; ANDRADE et al., 2015). Although the state of Goiás borders other states where this agent has already been diagnosed (Mato Grosso do Sul, Mato Grosso, Minas Gerais and Tocantins), this state has until now been considered free of $T$. vivax.

The present study had the objective of reporting the first case of infection by T. vivax in dairy cows in the state of Goiás, as well as some subsequent cases that were registered over a nine-month period (May 2015 to January 2016).

\section{Materials and Methods}

The index case of the disease in the state of Goiás occurred on a farm located in the municipality of Ipameri $\left(17^{\circ} 40^{\prime} 42^{\prime \prime}\right.$ South and $48^{\circ} 13^{\prime} 17^{\prime \prime}$ West), which is 190 kilometers away from the state capital, Goiânia. This farm had a herd composed of 161 Girolando cattle (5/8 Holstein and 3/8 Gir), including calves and cows, and presented an average production of 1,400 liters of milk per day.

The beginning of the outbreak, i.e. day zero (D 0) of the present study, was taken to be May 12, 2015. Three visits were performed. The first happens 29 days after the outbreak began, the second took place 39 days after the beginning of the outbreak, and the third was in October of 2016 (519 days after the begning of the outbreak). At the first visit, 15 cows were suspected of carrying the infection. Blood samples were collected from the jugular veins of all these animals, using the Vacutainer ${ }^{\varpi}$ system with EDTA, for direct observation of fresh blood samples, using a light microscope with a 40x objective. Blood smears from each sample were stained with May-Grünwald-Giemsa for morphological analysis on the trypanosomes. After presence of trypanosomatids in the animals' blood had been confirmed following the methodology described by Dávila et al. (1997) and Linhares et al. (2006).

With the objective of obtaining a confirmatory result regarding T. vivax, five blood samples that had been diagnosed as positive for T. vivax, by means of Giemsa staining, were subjected to PCR analysis (CORTEZ et al., 2009). All PCR products that showed high intensity of bands of the expected sizes were purified using the Silica Bead DNA Gel Extraction Kit (Fermentas, São Paulo, SP, Brazil). Purified amplified DNA fragments from positive samples were subjected to sequence confirmation in an automated sequencer (ABI Prism 310 Genetic Analyzer; Applied Biosystems/Perkin-Elmer) in both directions.

Also during this first visit, all animals that were found parasitized by trypanosomatids and which were presenting clinical signs indicative of the illness were treated with $3.5 \mathrm{mg} / \mathrm{kg}$ of diminazene aceturate (Ganaseg plus ${ }^{\oplus}$; Novartis Animal Health).

Is important to mention that it was also observed at the time of obtaining the farm history that, for more than three years, five international units of exogenous oxytocin were routinely administered to each lactating cow, intravenously (superficial cranial epigastric vein), before each milking. This was performed using a single needle and syringe each day for all animals. From the history-taking, it was noted that even though this practice had been used for at least three years, the outbreak coincidently started after the cattle owner acquired some animals at an auction.

Some subsequent cases are described in the present paper. Nonetheless, it is important to mention that this section of the study is still ongoing.

\section{Results}

\section{Report of the first outbreak}

Sixteen days before the beginning of the outbreak, eight cows were purchased at a Girolando (5/8 Holstein and 3/8 Gir) cattle auction in a neighboring municipality. According to the owner of the auction house, these animals originated from the state of Minas Gerais, in the "Triângulo Mineiro" region.

On day zero, the first cases of the outbreak were seen in three cows that originated from this auction, and milk production was reduced from 1,400 to 1,000 liters a day (28.5\%). Fifteen animals presented anemia, cachexia, watery eyes, bloody diarrhea (in one animal), weakness in hind limbs, hypersalivation, weight loss and recumbency. Six lactating cows died on the $6^{\text {th }}$ day after the beginning of the outbreak $(\mathrm{D}+6)$, and the owner correlated these deaths with nutritional causes, since coincidentally the feed provided for the animals had just been replaced with feed from a new supplier. Twenty days later $(\mathrm{D}+26)$, there was still no diagnosis for the problem and it was seen to have spread. Six other lactating cows died on this day, and another 20 sick cows were removed from the milking routine. All the cows that died had originated from the same farm.

Regarding blood samples collected from the animals (D+29), from 15 sick cows, five that originated from the auction and ten autochthonous cases, high levels of parasitemia due to trypanosomatids were in seven samples (all five cows from the cattle auction and two autochthonous cases) (Figure 1).

Morphometry results for trypanosomatids obtained in the present study, compared with those obtained by other researchers in different states of Brazil, are described in Table 1. Based on this table, it can be seen that the trypomastigote forms examined in the state of Goiás generally presented measurements of $\mathrm{KC}, \mathrm{PC}$, $A C$ and $F$ that were significantly smaller $(p \leq 0.05)$, than those obtained by other researchers in different states.

Four bovine whole-blood samples that had been collected during the first visit to the farm were tested by means of PCR. The amplicons resulted in 177 bp sequence with $98 \%$ homology, with others deposited in GenBank.

Regarding the results obtained from the second visit (D+39), at which blood samples from the entire herd were evaluated for trypomastigote forms and the history-taking showed that after treatment had been started, there were no further deaths and the animals presented clinical improvement. The parasites were detected in $25(40.9 \%)$ out of 61 cows, which were asymptomatic and had average hematocrit values of $21.41 \%$ (ranging from 13 to 32 ). 
Among these animals, three had previously been diagnosed and treated during the first visit $(\mathrm{D}+29)$.

During the third visit, which took place in October 2016 $(\mathrm{D}+519)$, through direct parasitological examinations (Giemsa staining) performed on the entire herd, trypomastigote forms were diagnosed in four lactating cows and two dry cows. The cattle owner reported that administration of oxytocin using a single needle and syringe still continued on the farm. However, before administering this product to each animal, the employee washed both the syringe and the needle in $70 \%$ alcohol. The owner also reported that another problem remained: the pregnancy percentage within the herd had decreased significantly, given that 18 out of 46 lactating cows had been diagnosed as empty (not pregnant) by a specialized veterinarian. This would further worsen the average daily milk production situation, considering that these 18 animals

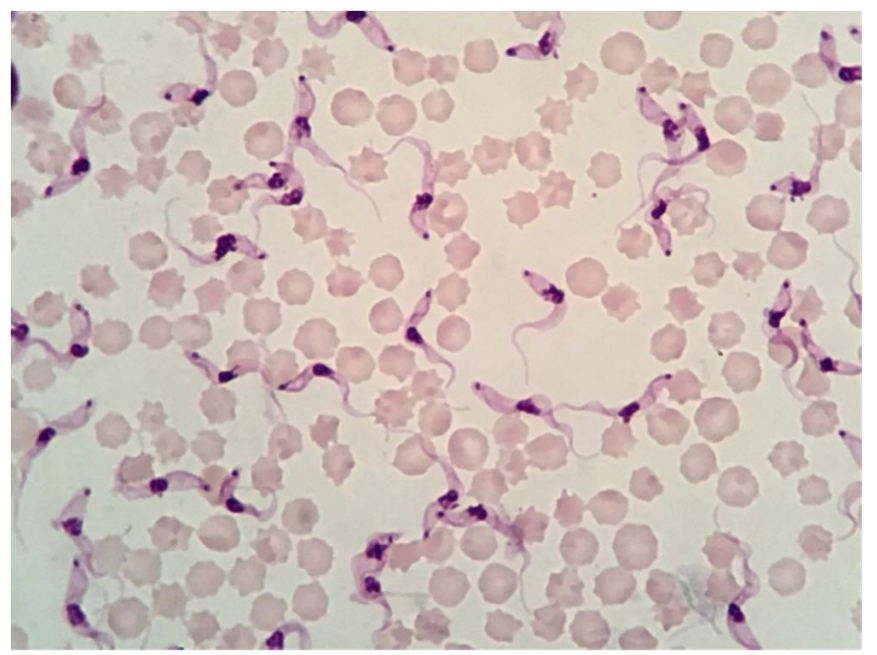

Figure 1. Blood smear demonstrating trypomastigote forms of Trypanosoma vivax found in a sample collected from a cow on a farm in the municipality of Ipameri, state of Goiás, central-western region of Brazil. May Grunwald/Giemsa staining at 1000x magnification. had been lactating for more than 14 months. According to the owner, the reproductive management of the cows on that farm consisted of fixed-time insemination protocols (each animal received three or four inseminations). If this protocol were not effective, a bull would be used for natural breeding among the animals that had not already become pregnant.

\section{Subsequent cases}

After this first outbreak of T. vivax in Goiás had been diagnosed, five other cases were detected in the municipalities of Cromínia, Bonfinópolis, Maripotaba, Morrinhos and Quirinópolis (Table 2 and Figure 2). In all of these subsequent cases, the farms were milk producers using Girolando cattle (5/8 Holstein and 3/8 Gir). Only the lactating cows presented positive diagnoses of $T$. vivax. These animals were receiving exogenous oxytocin at each milking, for which a single needle and syringe was shared for all the animals. It is important to emphasize that, in all of these cases, the owners had purchased animals at a cattle auction less than 30 days before the outbreak.

However, even though these producers were informed about the problem on their farms, some of them decided not to provide any further information for this study. Their motive was that they feared that they might become disadvantaged in the animal sales market, since some of them routinely sold cows. On the other hand, it is important to emphasize that such attitudes are certainly contributing towards faster dissemination of this protozoon in the state of Goiás, especially in Girolando herds.

\section{Discussion}

The first report of T. vivax in Brazil was in a buffalo, in the state of Pará, in the northern region of this country, in 1972 (SHAW \& LAINSON, 1972). Approximately 20 years ago, this protozoon was commonly found in the swampy areas of the Brazilian Pantanal, which mainly covers some areas of the states

Table 1. Average values $(\mu \mathrm{m})$ of morphometric measurements of Trypanosoma vivax obtained from bovines on the state of Goiás, compared to other states from Brazil.

\begin{tabular}{|c|c|c|c|c|c|c|c|c|c|}
\hline \multirow{2}{*}{ State } & \multirow{2}{*}{ Authors (Year) } & \multicolumn{8}{|c|}{ Mean obtained values $(\mu \mathrm{m})^{*}$} \\
\hline & & PK & KC & PC & $\mathrm{AC}$ & $\mathbf{F}$ & $\mathbf{L}$ & KI & NI \\
\hline Goiás & Data from this study & $\begin{array}{c}1.02 \mathrm{~A} \\
( \pm 0.63)\end{array}$ & $\begin{array}{c}5.65 \mathrm{~A} \\
( \pm 0.86)\end{array}$ & $\begin{array}{c}6.64 \mathrm{~A} \\
( \pm 0.87)\end{array}$ & $\begin{array}{c}7.42 \mathrm{~A} \\
( \pm 1.29)\end{array}$ & $\begin{array}{c}5.15 \mathrm{~A} \\
( \pm 1.61)\end{array}$ & $\begin{array}{l}18.30 \mathrm{~A} \\
( \pm 2.14)\end{array}$ & $\begin{array}{c}1.21 \\
( \pm 0.16)\end{array}$ & $\begin{array}{c}0.77 \\
( \pm 0.17)\end{array}$ \\
\hline Tocantins & Linhares et al. (2006) & $\begin{array}{c}0.96 \mathrm{~A} \\
( \pm 0.45)\end{array}$ & $\begin{array}{c}6.24 \mathrm{~B} \\
( \pm 1.06)\end{array}$ & $\begin{array}{c}7.25 \mathrm{~B} \\
( \pm 0.95)\end{array}$ & $\begin{array}{c}5.87 \mathrm{~B} \\
( \pm 1.79)\end{array}$ & $\begin{array}{c}6.29 \mathrm{~B} \\
( \pm 2.60)\end{array}$ & $\begin{array}{l}19.42 \mathrm{~B} \\
( \pm 3.35)\end{array}$ & $\begin{array}{c}1.16 \\
( \pm 0.90)\end{array}$ & $\begin{array}{c}1.24 \\
( \pm 0.50)\end{array}$ \\
\hline Mato Grosso & Silva et al. (1996) & $\begin{array}{c}1.02 \mathrm{~A} \\
( \pm 1.16)\end{array}$ & $\begin{array}{c}6.10 \mathrm{~B} \\
( \pm 1.29)\end{array}$ & $\begin{array}{c}7.18 \mathrm{~B} \\
( \pm 1.18)\end{array}$ & $\begin{array}{c}5.40 \mathrm{C} \\
( \pm 1.63)\end{array}$ & $\begin{array}{c}6.15 \mathrm{~B} \\
( \pm 2.38)\end{array}$ & $\begin{array}{l}18.73 \mathrm{~A} \\
( \pm 3.80)\end{array}$ & $\begin{array}{c}1.17 \\
( \pm 0.91)\end{array}$ & $\begin{array}{c}1.50 \\
( \pm 0.72)\end{array}$ \\
\hline Pará & Shaw \& Lainson (1972) & $\begin{array}{c}0.65 \mathrm{~B} \\
( \pm 0.25)\end{array}$ & $\begin{array}{c}6.16 \mathrm{~B} \\
( \pm 0.57)\end{array}$ & $\begin{array}{l}7.60 \mathrm{C} \\
( \pm 0.57)\end{array}$ & $\begin{array}{l}8.22 \mathrm{D} \\
( \pm 1.08)\end{array}$ & $\begin{array}{c}6.92 \mathrm{C} \\
( \pm 1.03)\end{array}$ & $\begin{array}{l}22.77 \mathrm{C} \\
( \pm 1.38)\end{array}$ & - & $\begin{array}{c}0.94 \\
( \pm 0.24)\end{array}$ \\
\hline Maranháo & Guerra et al. (2008) & $\begin{array}{c}1.35 \mathrm{C} \\
( \pm 0.37)\end{array}$ & $\begin{array}{c}6.40 \mathrm{~B} \\
( \pm 0.79)\end{array}$ & $\begin{array}{l}7.64 \mathrm{~B} \\
( \pm 1.16)\end{array}$ & $\begin{array}{c}6.75 \mathrm{E} \\
( \pm 1.08)\end{array}$ & $\begin{array}{c}6.01 \mathrm{~B} \\
( \pm 1.31)\end{array}$ & $\begin{array}{l}19.94 \mathrm{~B} \\
( \pm 1.93)\end{array}$ & $\begin{array}{c}1.20 \\
( \pm 0.14)\end{array}$ & $\begin{array}{c}1.15 \\
( \pm 0.23)\end{array}$ \\
\hline Minas Gerais & Carvalho et al. (2008) & $0.90(---)$ & $6.64(---)$ & $7.55(--)$ & $7.46(---)$ & $6.22(---)$ & $19.89(---)$ & $1.04(---)$ & $1.14(---)$ \\
\hline
\end{tabular}

${ }^{*} \mathrm{PK}=$ measurement of the posterior extremity of kinetoplasts; $\mathrm{KC}=$ measurement of kinetoplasts at the middle of the core; $\mathrm{PC}=$ measurement from the posterior extremity to the middle of the core; $\mathrm{AC}=$ measurement from the anterior extremity to the core; $\mathrm{F}=$ measurement of free flagellum; $\mathrm{L}=$ total length, including the flagellum; KI = kinetoplast index (PC/KC ratio); NI = nuclear index (PC/AC ratio). 


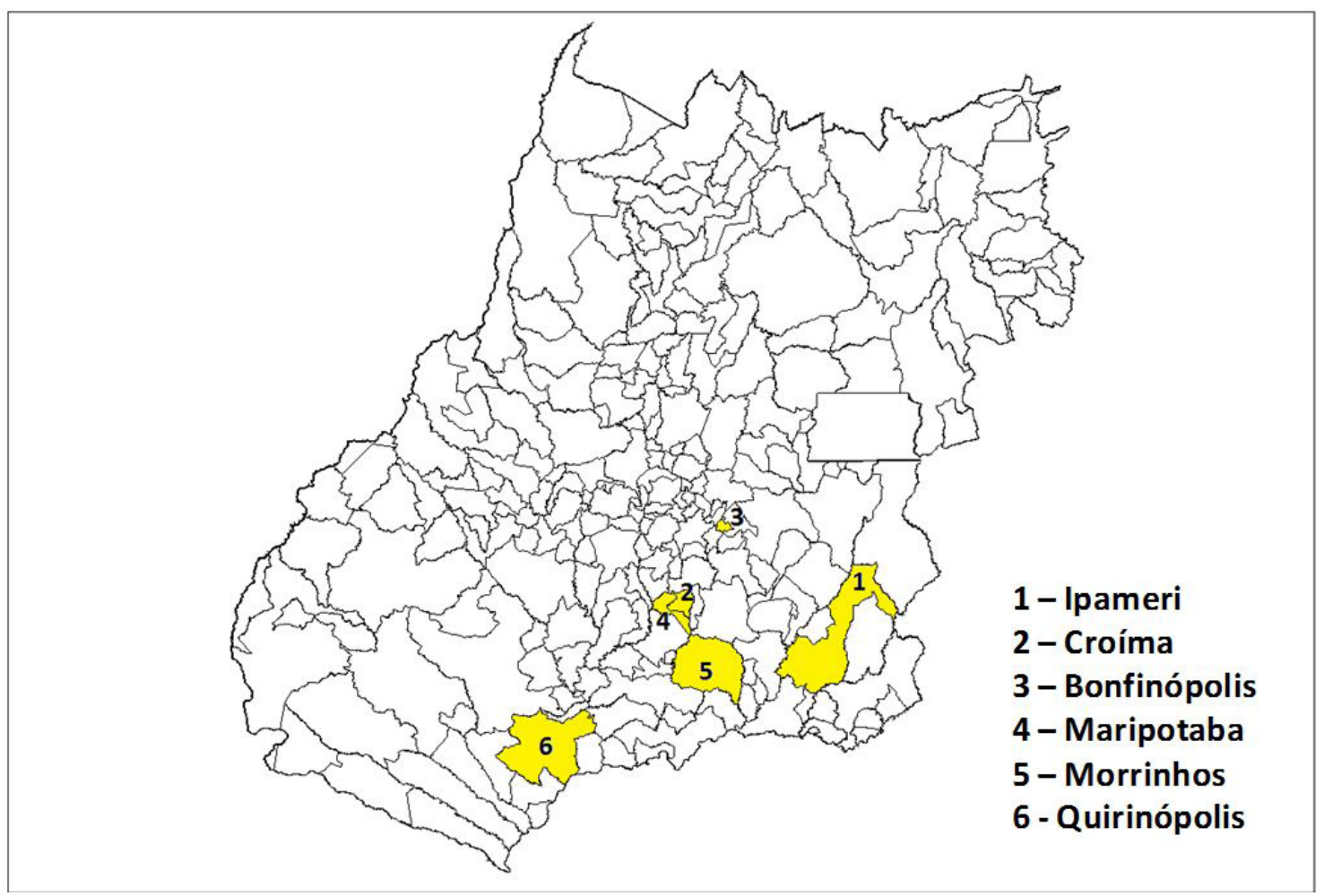

Figure 2. Municipalities in the state of Goiás in which cases of T. vivax were registered among Girolando (5/8 Holstein and 3/8 Gir) lactating cows, between May 2015 and January 2016.

Table 2. Subsequent cases of Trypanosoma vivax diagnosed by means of direct parasitological techniques (Giemsa staining) in the state of Goiás, central-western region of Brazil, between May 2015 and January 2016.

\begin{tabular}{|c|c|c|c|c|}
\hline History (confirmation method) & Period of detection & Municipality / city & $\begin{array}{l}\text { Total amount of } \\
\text { animals on analyzed } \\
\text { herds }\end{array}$ & $\begin{array}{c}\text { Total amount and } \\
\text { category of animals } \\
\text { in which T. vivax was } \\
\text { diagnosed } \\
\end{array}$ \\
\hline $\begin{array}{l}\text { Regarding the first outbreak (direct } \\
\text { parasitological test, PCR and genetic } \\
\text { sequencing) }\end{array}$ & May 2015 & Ipamerí & 149 & 24 cows (lactating) \\
\hline $\begin{array}{l}\text { Regarding the third visit in the local } \\
\text { where was diagnosed the first } \\
\text { outbreak (direct parasitological test) }\end{array}$ & October 2016 & Ipameri & 87 & $\begin{array}{l}04 \text { cows lactatin gand } \\
02 \text { drycows }\end{array}$ \\
\hline \multirow{5}{*}{$\begin{array}{l}\text { Subsequent cases } \\
\text { (direct parasitological test) }\end{array}$} & July 2015 & Cromínia & 45 & 01 cow (lactating) \\
\hline & August 2015 & Bonfinópolis & $>500$ & 17 cows (lactating) \\
\hline & January 2016 & Maripotaba & $>200$ & 01 cow (lactating) \\
\hline & January 2016 & Morrinhos & $>500$ & 12 cows (lactating) \\
\hline & January 2016 & Quirinópolis & Non informed & 02 cows (lactating) \\
\hline
\end{tabular}

of Mato Grosso and Mato Grosso do Sul, in the central-western region of Brazil. This led researchers, at that time, to describe this agent as mostly restricted to those regions (SILVA et al., 1996; PAIVA et al., 2000). As time passed and further studies were conducted, it could be seen that the protozoan was, little by little, also reaching other regions of the country.

After the first report in the state of Pará, new cases continued with cattle in the state of Amapá (northern region) in 1981 (SERRA-FREIRE, 1981), Mato Grosso in 1995 (SILVA et al., 1996), Mato Grosso do Sul in 1997 (PAIVA et al., 2000), Paraíba (northeastern region) in 2002 (BATISTA et al., 2007), Maranhão (northeastern region) in 2003 (GUERRA et al., 2008), Tocantins (northern region) in 2005 (LINHARES et al., 2006), Minas Gerais (southeastern region) in 2007 (CARVALHO et al., 2008), São Paulo (southeastern region) in 2008 (CADIOLI et al., 2012), Rio Grande do Sul (southern region) in 2009 (SILVA et al., 2009), Pernambuco (northeastern region) in 2010 (PIMENTEL et al., 2012) and Alagoas (northeastern region) in 2013 (ANDRADE et al., 2015).

The clinical signs observed among cows in the state of Goiás in the present study were concordant with those observed by Dagnachew \& Bezie (2015) and Linhares et al. (2006). According to these authors, although symptoms may vary with differing 
virulence of $T$. vivax strains, acute cases usually present anemia (with hematocrit below 20\%), weight loss and death (if the animals are not treated). In the past, T. vivax was considered endemic in the west central regions of pantanal (MS) with animals almost all asymptomatic. On the other hand, is important to report that in the recent years, new outbreaks, including in the present study, have revealed severe nervous signs, uncommon for Brazil and South America (CADIOLI et al., 2012). Because of this, these researchers emphasized that, because of the variety of illnesses that present similar clinical signs, it is essential to perform complementary laboratory tests in order to correctly diagnose $T$. vivax.

Regarding economic losses, outbreaks caused by bovine trypanosomiasis need to be highlighted, mainly because of animal mortality and reductions in production. Carvalho et al. (2008), in Minas Gerais, reported a decrease in milk production of $27 \%$. In the present study, the mortality rate among the cows after the outbreak was $22.7 \%$, and the fall in daily milk production was 28.5\%, 15 days after the arrival of animals bearing T. vivax.

Other researchers have also observed that introduction of infected animals in areas free of such disease is one of the factors leading to outbreaks (LINHARES et al., 2006; BATISTA et al., 2007; CADIOLI et al., 2012). The results obtained from this farm in Ipameri, as well as those from the other farms subsequently diagnosed with cases, reinforce this inference described by the above mentioned authors, since outbreaks only occurred soon after the introduction of new animals to the herds. Moreover, in the present study, the animals on all of these six farms were Girolando cattle (5/8 Holstein and 3/8 Gir) with an aptitude for milk production, and only lactating cows presented $T$. vivax.

The hypothesis that T. vivax was introduced through transportation of positive animals from the state of Minas Gerais is reinforced based on the histories in the cities in which T. vivax was diagnosed in the present study. All of these municipalities in Goiás are very close to the border of this state with Minas Gerais, and the municipalities along the other side of the border, in Minas Gerais, already have confirmed diagnoses of this protozoon (SNA, 2014).

After $T$. vivax has arrived on a farm, there are basically two transmission routes for this agent to reach animals: by means of mechanical vectors or through the iatrogenic form. In the state of Mato Grosso, Silva et al. (1996) reported that animal-to-animal transmission in the region was related to presence of mechanical vectors such as tabanids. In the Brazilian semiarid region, an outbreak of $T$. vivax was correlated with large numbers of Stomoxys calcitrans. Cadioli et al. (2012), who diagnosed the first outbreak in the state of São Paulo, caused by animals that originated in the state of Mato Grosso do Sul, were able to verify that transmission between cattle happened under conditions of low levels of rainfall. This indicates that other factors were also involved in this outbreak, such as absence of tabanids and large numbers of Haematobia irritans and $S$. calcitrans, whose population increase may have been related to use of residues from sugar and alcohol plants, on the sugar cane fields that surrounded the dairy farm. However, in the present study, on the farm where the first outbreak of T. vivax occurred, and also on all five farms where subsequent cases were confirmed, there was no abundant presence of tabanids, S. calcitrans or even $H$. irritans.
Regarding the iatrogenic form of infection, it is important to emphasize that on all farms where $T$. vivax was diagnosed, daily administrations of five international units (IU) of exogenous oxytocin were administered daily (intravenously into the cranial superficial epigastric vein) to the lactating cows, before each milking. This hormone is involved in different functions, such as uterine contractions during parturition, mating and milk letdown. In Girolando animals, for the flow of milk to go down quickly to the cow's teats, it is necessary to have the presence and stimulus of the calf near the mother, which leads right after wards to natural release of endogenous oxytocin into the cow's bloodstream.

Several management systems for Girolando cattle involve milking without the presence of calves, mainly due to labor and service optimization (quicker milking). Hence, producers opt for iatrogenic administration of exogenous oxytocin before each milking, which increases the speed of milk letdown to the teats, thus resulting in shorter milking processes (ARAÚJO et al., 2013).

The main problem in this regard is that in the present study, all the farms implemented this procedure using a single needle and syringe ( 1 milliliter) for all animals. On the other hand, it is important to emphasize that problems caused by $T$. vivax always appeared after acquisition of new animals. In other words, acquisition of new animals carrying $T$. vivax, allied to the habit of administering exogenous oxytocin to cows before every milking using the same needle and syringe, which was possibly contaminated, seems to have been the main means of spreading the agent in the state of Goiás, between farms and between animals on the same farm, respectively. On the six dairy farms visited in the present study, only lactating cows were infected by this protozoon, and, syringes containing exogenous oxytocin mixed with blood from the animals were observed at the milking site, which emphasizes the hypothesis of the preceding paragraph.

Inefficacy of $7 \mathrm{mg} / \mathrm{kg}$ of diminazene against $T$. vivax was reported by Cadioli et al. (2012). Recently, for cattle, the reference drug for treatment against this protozoon has become isometamidium, which was only released in 2016 for commercialization in Brazil. The problem for the farms of the present study was that, when the first outbreak and subsequent cases occurred, isometamidium had not yet become available on the market in Brazil, except for specific situations with approval from MAPA (Brazilian Ministry of Agriculture, Livestock and Supply) to import the drug. This approval was taking two to three months to obtain.

According to Linhares et al. (2006), after primary infection by $T$. vivax has become established in animals on a given farm, mortality among these cattle usually becomes a rarer occurrence, except when new animals that are free from infection are introduced into the herd. These researchers also stated that one complication that this agent can lead to, in herds that are already infected, is the possibility of reproductive problems in cows, caused by T. vivax. In the present study, even though the owner reported that reproductive problems had occurred, further studies need to be conducted in order to confirm the hypothesis that $T$. vivax was the real cause. Another important point regarding the results from direct parasitological examinations (Giemsa staining) in the present study, is the fact that this diagnostic method is not very sensitive. Thus, if this methodology is used for eliminating animals from a herd, unsatisfactory results may appear. 
In summary, the present study reported the first case of Trypanosoma vivax in the state of Goiás, in the central-western region of Brazil. In addition to the index case, which was diagnosed in the municipality of Ipameri, five others occurred (in the municipalities of Cromínia, Bonfinópolis, Maripotaba, Morrinhos and Quirinópolis) over an eight-month period, which demonstrates the rapid spread of the disease in this state. This protozoon was diagnosed only in Girolando lactating cows. Acquisition of new animals carrying T. vivax, allied to the practice of administering oxytocin to cows before each milking, using a single needle and syringe for all of them, may have been the main causes of dissemination of the agent in the state of Goiás, between farms and between animals on a single farm, respectively. Thus, studies on additional farms, with evaluation of epidemiological aspects and with the aid of molecular tools is needed to elucidate the real spatial distribution of T. vivax in the state of Goiás, along with attempts to compare the genetic profile of this protozoon with those diagnosed in other Brazilian states.

\section{References}

Andrade AQA No, Afonso JAB, Mendonça CL, Souto RJC, André MR, Machado RZ. Surtos de tripanossomíase em bovinos leiteiros no agreste dos estados de Pernambuco e Alagoas. Biologico 2015; 77(S2): 143.

Araújo WAG, Carvalho CGV, Marcondes MI, Sacramento AJR, Paulino PVR. Ocitocina exógena e a presença do bezerro sobre a produção e qualidade do leite de vacas mestiças. Braz J Vet Res Anim Sci 2013; 49(6): 465-470. http://dx.doi.org/10.11606/issn.1678-4456.v49i6p465-470.

Batista JS, Riet-Correa F, Teixeira MMG, Madruga CR, Simōes SDV, Maia TF. Trypanosomiasis by Trypanosoma vivax in cattle in the Brazilian semiarid: description of an outbreak and lesions in the nervous system. Vet Parasitol 2007; 143(2): 174-181. PMid:16965857. http://dx.doi. org/10.1016/j.vetpar.2006.08.017.

Cadioli FA, Barnabé PA, Machado RZ, Teixeira MCA, André MR, Sampaio PH, et al. First report of Trypanosoma vivax outbreak in dairy cattle in São Paulo state, Brazil. Rev Bras Parasitol Vet 2012; 21(2): 118-124. PMid:22832751. http://dx.doi.org/10.1590/S1984-29612012000200009.

Carvalho AU, Abrão DC, Facury EJ Fo, Paes PRO, Ribeiro MFB. Occurrence of Trypanosoma vivax in Minas Gerais state, Brazil. Arq Bras Med Vet Zootec 2008; 60(3): 769-771. http://dx.doi.org/10.1590/ S0102-09352008000300037.

Cortez AP, Rodrigues AC, Garcia HA, Neves L, Batista JS, Bengaly $\mathrm{Z}$, et al. Cathepsin L-like genes of Trypanosoma vivax from Africa and south America: characterization, relationships and diagnostic implications. Mol Cell Probes 2009; 23(1): 44-51. PMid:19063960. http://dx.doi. org/10.1016/j.mcp.2008.11.003.

Dagnachew S, Bezie M. Review on Trypanosoma vivax. Afr J Basic Appl Sci 2015; 7(1): 41-64.

Dávila AMR, Ramirez L, Silva RAMS. Morphological and biometrical differences among Trypanosoma vivax isolates from Brazil and Bolivia. Mem Inst Oswaldo Cruz 1997; 92(2): 357-358. PMid:9332601. http:// dx.doi.org/10.1590/S0074-02761997000300010.

Guerra RMSN, Feitosa AB Jr, Santos HP, Abreu-Silva AL, Santos ACG. Biometry of Trypanosoma vivax found in a calf in the state of Maranhão, Brazil. Cienc Rural 2008; 38(3): 833-835. http://dx.doi.org/10.1590/ S0103-84782008000300041.

Linhares GFC, Dias FC Fo, Fernandes PR, Duarte SC. Tripanossomíase em bovinos no município de Formoso do Araguaia, Tocantins (relato de caso). Cienc Anim Bras 2006; 7(4): 455-460.

Paiva F, Lemos RAA, Nakasato L, Mori AE, Brum KB, Bernardo KC. Trypanosoma vivax em bovinos no Pantanal do Estado do Mato Grosso do Sul, Brasil: I.-Acompanhamento clínico, laboratorial e anatomopatológico de rebanhos infectados. Rev Bras Parasitol Vet 2000; 9(2): 135-141.

Pimentel DS, Ramos CAN, Ramos RAN, Araújo FR, Borba ML, Faustino MAG, et al. First report and molecular characterization of Trypanosoma vivax in cattle from state of Pernambuco, Brazil. Vet Parasitol 2012; 185(2): 286-289. PMid:22054681. http://dx.doi.org/10.1016/j. vetpar.2011.10.019.

Serra-Freire NM. Oiapoque - outro foco de Trypanosoma vivax no Brasil. Rev Bras Med Vet 1981; 4(4): 30-31.

Shaw JJ, Lainson R. Trypanosoma vivax in Brazil. Ann Trop Med Parasitol 1972; 66(1):25-32.

Silva AS, Costa MM, Polenz MF, Polenz CH, Teixeira MMG, Lopes STA, et al. Primeiro registro de Trypanosoma vivax em bovinos no Estado do Rio Grande do Sul, Brasil. Cienc Rural 2009; 39(8): 2550-2554. http://dx.doi.org/10.1590/S0103-84782009005000189.

Silva RAMS, Silva JA, Schneider RC, Freitas J, Mesquita D, Mesquita $\mathrm{T}$, et al. Outbreak of trypanosomiasis due to Trypanosoma vivax (Ziemann, 1905) in bovines of the Pantanal, Brazil. Mem Inst Oswaldo Cruz 1996; 91(5): 561-562. PMid:9137742. http://dx.doi.org/10.1590/S007402761996000500005 .

Sociedade Nacional de Agricultura- SNA. Faemg mapeia regiôes de MG com casos de tripanossomose [online]. Rio de Janeiro: SNA; 2014 [cited 2016 Apr 12]. Available from: http://sna.agr.br/pecuaria-faemg-iramapear-regioes-de-mg-com-casos-de-tripanossomose 